Darko Dimovski, LL.D.

Professor, Faculty of Law, University of Niš, Serbia

Ivan Milić, LL.D.

Teaching Assistant, Faculty od Law, University of Novi Sad, Serbia

UDK: 343.352(497:114-672EU)

Рад примљен: 30.09 .2018$.

Рад прихваћен: 23.10.2018.

\title{
THE IMPACT OF CORRUPTION ON NATIONAL COMPETITIVENESS ${ }^{* *}$
}

\begin{abstract}
Corruption is a global phenomenon that can be identified in all countries. Although visible everywhere, corruption usually affects poorer countries, limiting the progress of the national economy and taking away the resources needed for education, health care and other public goods and services. However, the private sector also faces this global problem that jeopardizes corporate identity, distorts trust among business partners, and ruins the reputation of companies. The paper primarily provides a theoretical overview of corruption, with a special emphasis on the role of corruption in achieving macroeconomic stability of a country. Changes in the level of corruption in the Republic of Serbia are being analyzed in comparison with the European Union countries in the period from 2009 to 2016, based on the Corruption Perception Index (CPI). The paper also analyses the impact of corruption on national competitiveness in order to assess the degree of their interdependence. The research in this paper may be useful for policy makers in the context of the future development of anti-corruption policy and strategy.
\end{abstract}

Key words: corruption, competitiveness, corruption perception index.

\footnotetext{
*dimovski@prafak.ni.ac.rs

${ }^{* *}$ This paper was presented at the International Scientific Conference "Law in the context of addressing the Challenges of the Contemporary World", held at the Faculty of Law, University of Niš, on $13^{\text {th }}-14^{\text {th }}$ April 2018.

The paper is a result of research within the projects 179066 and 179046 , funded by the Ministry of Education, Science and Technological Development of the Republic of Serbia
} 


\section{Introduction}

Corruption is not a phenomenon of a recent date. The first cases of corruption were recorded in the distant past, in ancient Greece and Rome. Nowadays, corruption is characterized by its actuality, high degree of social danger and new forms that have found favourable conditions in many areas, both in the public and the private sector.

Corruption is a global threat and a serious impediment to the economic development of countries, since it redirects limited resources to inadequate use. There is no country that is completely immune to corruption. Even countries with the most successful and longest market tradition face illegal economic and political exploitation. Corruption increases inequality and promotes injustice, endangering macroeconomic stability, especially in underdeveloped countries and parts of the world.

Corruption disrupts the fundamental values of social relations of every democratic and civil society. It jeopardizes the rule of law, trust in public institutions and legal state, justice, equality and security of citizens. Corruption increases and sharpens social differences, encourages efforts to live above opportunities thanks to dishonest work, and to get rich by downplaying the value of honest work. It hampers the development of entrepreneurial climate and political cultu$\mathrm{re}$, and other basic social values. Among other factors, the economic development of a country depends on the ability to prevent the risk of corruption. Creating and encouraging the will of citizens and determination of the authorities are crucial in combating corruption. Therefore, apart from legal responsibility, everyone in the public and the private sector has the responsibility in performing jobs.

Taking into consideration the importance that corruption has for national competitiveness, this paper analyzes the interdependence between corruption and national competitiveness in order to evaluate their relationship. In addition, corruption in the Republic of Serbia in the period from 2009 to 2016 is analysed based on the Corruption Perception Index (CPI). Given the Serbia's intention to access the European Union, Serbia is benchmarked against the EU countries according to the CPI.

The paper is organized into two sections, with several subsections. In the first part of this paper, the authors provide a theoretical overview of corruption in the public and private sector and the role that corruption plays in its macroeconomic environment. In the second part, which refers to research results, an analysis of corruption in Serbia and its position compared to the EU countries is provided, including an analysis of the impact that corruption has on national competitiveness. 


\section{Theoretical background}

\subsection{The conceptual basis of corruption}

Corruption is defined as a relationship based on abuse of authority in the public or private sector in order to gain personal benefit or benefit for others. ${ }^{1}$ It occurs where there is a possibility and interest. Corruption can be: petty, small or survival corruption, or large, sporadic or systemic; simple or complex; it can also be a corruption at the lowest, street level, contracting or corruption in public administration, political, commercial and judicial corruption. ${ }^{2}$

Corruption, as abuse of public authority to gain personal benefits, exists if there is a deliberate violation of the impartiality principle in the decision-making process in order to gain some advantages. Corruption occurs when the official illegally places an individual interest over the interests of people and ideals he/she should serve. Corruption can be defined in a broad and narrow sense. ${ }^{3}$

Since the very beginning of human society and the formation of the first states, corruption in a wider sense represents a socially negative phenomenon which has developed and gained its manifestations depending on the historical, social, economic, political and other conditions causing harmful consequences to society. Corruption in a wider sense entails the early forms of abuse of social position and reputation in performing certain public functions (deputies, leaders of certain political parties, leaders of charities or associations, etc.) that do not have the character of purely state functions, such as: doing a favor based on the friendship, giving gifts, creating certain relationships contrary to the basic moral, customary and other accepted codes, giving the so-called tips in the form of petty bribes to state and public officers, misuse of funds for advertising and economic propaganda, fake fees for fictitious experts, etc. Corruption in the narrow sense includes the abuse of an official position, receiving and giving bribes, illegal mediation, fraud at work, forgery of official documents, unconscientious work, etc. ${ }^{4}$

Corruption is present in both developed and poor countries, which implies that poverty and transition are not the main causes of corruption. Above all, corruption depends on the state system and morality of the nation. Of course, it

1 Konstantinović-Vilić, S, Nikolić-Ristanović, V, Kostić, M, Kriminologija, Law Faculty, Niš, 2009, p. 179.

2 Morris, S. D., Forms of Corruption, CESifo DICE Report 2/2011, Middle Tennessee State University, 2011, pp. 10-14.

3 Jelačić, M., Korupcija, Ministry of Interior of the Republic of Serbia, Belgrade, 1996, pp. 42-43.

4 Petrović, Z., Krivično delo zloupotrebe službenog položaja, Privredni kriminal i korupcija, Institute of Criminological and Sociological Research, Belgrade, 2001, p. 205. 
does not depend on one factor, but usually occurs when there is a wider range of factors, such as economic, social, cultural, historical, political, legal, and others. ${ }^{5}$ Corruption particularly comes to the fore in unstable systems, at the time of social turbulence accompanied by the impoverishment of public officials, but also the weakening of the legal and economic control mechanisms of the state and society as a whole. Corruption is not easy to stabilize at a certain low level, especially when it begins to attack and conquer those parts of society that should be the barrier against corruption, such as the judiciary and the police.

\subsection{Different approaches to the concept of corruption}

In defining the concept of corruption, we may observe several components: ${ }^{6}$

- Economic component - Corruption destroys the pillars of the economic system of a society. It is the cause of many disruptions since it disrupts the functioning of the basic segments of the economic system: production, consumption, distribution and exchange. On the other hand, it is a consequence of deeper socioeconomic contradictions and the functioning of certain economic laws in the economic system of society and in the field of international economic relations, such as: laws of supply and demand, value law, crisis of hyperproduction, inflation, competition law at the domestic and the global market, and others. Contrary to the universal principle of free trade, corruption can quickly and efficiently help acquire better market position in terms of placing various goods on domestic and foreign markets. ${ }^{7}$ Behind powerful companies, such as transnational ones, are their governments with special organizations that give full support to this way of achieving economic, political and military domination.

- Legal component - Among all norms that regulate relationships between people (economic, cultural, etc.), legal norms have the most important role in regulating a whole range of relationships in a state or society. They prescribe what is allowed and what is not. Therefore, their observance is ensured through criminal and other sanctions, but always in the interest of the state or the ruling class. ${ }^{8}$ Corruption can also be defined as a special type of unfounded wealth which is forbidden or immoral. This is the case where the property of one (corrupted) person increases without any legal

5 Milošević, Z. Političke stranke i korupcija, Political Review, no. 1, Belgrade, 2007, p. 23-38.

6 Jelačić, M., op.cit., pp. 12-40.

7 Fitzsimons, V., Economic Models of Corruption, Corruption and Development, The AntiCorruption Campaigns, 2007, pp. 8-11.

8 Kaufmann, D., Vicente, P.C., Legal Corruption, World Bank Institute, 2005, pp. 3-5. 
reason, and the property of another person (e.g., the bribe provider) simultaneously decreases.

- Criminological component - Corruption is part of economic crime and, according to the degree of social danger, it represents its most difficult aspect as it affects the basic state foundations and its economic system. ${ }^{9}$ Criminology defines corruption as a set of all punishable actions undertaken by the public officer who, abusing its position and the institution in which it works, damages the public interest to such an extent and in such a way as to undermine the trust of citizens and the general public in state and society.

- Moral component - Corruption erodes the morale of a society through endangering or destruction of its social, economic, political and legal institutions. It breaks down basic human values, such as: freedom, dignity, the human rights of the citizen, and his/her need to create and apply new knowledge and products (material and spiritual). ${ }^{10}$ Corruption is contrary to the basic morally correct principles that individuals, more or less knowingly and implicitly, know.

- Social component - Like all other deviations, corruption has origins in the social basis of society. Namely, the sharp social crisis increasingly threatens the foundation of society, i.e. state, economic, cultural and other institutions. Corruption is connected and conditioned by the appearance of bureaucracy and technocracy, and manifests itself in the unlawful behavior of some officials and other persons who are entrusted by the law to perform state or other public duties in public institutions. ${ }^{11}$

- Historical component - As a socially harmful phenomenon, corruption in a certain sense has its origin in ancient days, endangering the well-known empires (Roman, Turkish, Austro-Hungarian, British, Russian, etc.). It is an indisputable fact that there were always people who wanted to gain some benefits or privilege, which they did not have rights to under the existing moral and legal norms. In order to obtain unlawful benefits, those people skillfully used corruption as a method of achieving their goals; so, they gave

9 Benson, M.L. and T.D. Madensen (2007). Situational Crime Prevention and White-Collar Crime, in: Pontell, H.N. and G. Geis, International Handbook on White-Collar and Corporate Crime, New York: Springer, pp. 609- 626.

10 Kreikebaum, H., Corruption as a moral issue, Social Responsibility Journal, Vol. 4 Issue: 1/2, 2008, pp. 82-88.

11 Granovetter, M., The Social Construction of Corruption, The Norms, Beliefs and Institutions of 21st Century Capitalism: Celebrating the 100th Anniversary of Max Weber's The Protestant Ethic and the Spirit of Capitalism, Cornell University, 2004, p. 4. 
gifts (in goods or money), extended various favors (material, etc.) or other benefits to those people who the realization of this benefit depended on. ${ }^{12}$

\subsection{The role of corruption in the macroeconomic stability of a country as one of the important determinants of national competitiveness}

Although the macroeconomic environment is considered as the factor which cannot accelerate economic growth by itself, it is a necessary condition for improving the competitiveness of a country.

The institutional environment is the essential component of the macroeconomic and, therefore, business environment. Its role is reflected in ensuring the institutional security of citizens in order to be engaged in economic activities. Citizens would only invest if they believe in benefits from a particular business or investment, without unnecessary waste of time and money in the protection of property and controlling the obligation fulfillment of all contracting parties. This primarily depends on the level of trust in society, but formally it depends on institutional capacity to provide the basic level of security and protection of property rights. The institutional role in improving the level of competitiveness is achieved through the provision of sufficient transparency and efficiency level of the public sector.

One of the fundamental roles of the state is to provide security to its citizens, which is a minimum requirement for the performance of economic activities. Corruption, violence, racketeering, organized crime, terrorism (etc.) have a significant negative impact on private investment and economic transactions.

The quality of a business environment is significantly influenced by the degree of corruption. As the abuse of public power for private purposes, corruption affects competitiveness in the following ways: it reduces a desire for investment since economic actors consider corruption as a special type of tax; corruption leads to inadequate allocation of human capital as it is primarily engaged in rentseeking activities, not in productive work; corruption leads to irrational public spending as public representatives allocate funds less to the improvement of public welfare but more to the opportunities that lead to their personal wealth; corruption reduces the quality of existing infrastructure and public services through inadequate public procurement contracts. ${ }^{13}$

12 MacDonald, R., Tariq Majeed, M., Causes of Corruption in European Countries: History, Law, and Political Stability, Europe's Post-Crisis Stability - An Interdisciplinary Approach, Berlin, Germany, 2011, pp. 10-11.

13 WEF (2016-2017). Global Competitiveness Report. Geneva: World Economic Forum, p. 46. 
Economically, corruption leads to a reduction in national wealth. It is often responsible for directing scarce public resources to non-economic high-profile projects, such as dams, power plants, refineries and pipelines, to the detriment of less spectacular but basic infrastructure projects, such as schools, hospitals and roads, or supplying rural areas with electricity and water. In addition, it prevents the development of the market structure, distorts competition, and thus discourages investment. ${ }^{14}$

The public sector efficiency also has a significant impact on the business environment and is reflected above all through the efficiency of administrative services. Administrative efficiency is significantly reflected in business demographics, as bulky and corrupt bureaucracy demotivates investments and reduces the efficiency of companies' operations (paying various types of taxes, complicated judicial system, (non)compliance with regulations, obtaining all necessary permits, etc.). Corporate ethics can also encourage companies, investors and society to be engaged in economic activities. Both formal and informal business norms play a crucial role in the business environment where high ethical standards among business partners contribute to building confidence..$^{15}$

Bureaucratic corruption leads to the wrong allocation of public resources. Once corruption enters bureaucracy, public officials can create artificial bottlenecks as a means of extorting money, which further leads to a decrease in productivity and quality of services. ${ }^{16}$

The risk of corruption increases with the number and duration of transactions, number of people involved, and the simplicity and standardization of procedures. The most noticeable signs of the negative impact of corruption are the so-called "white elephants", projects that completely ignore public demand or fall shortly after completion. In addition to preferring wrong companies and projects, corruption reduces productivity as a result of reduced bureaucracy efforts and reduced quality of public investment.

The argument that corruption can be limited by minimizing the public sector reflects the faith of economists in the market and their lack of trust in politicians. Research shows that the size of the state budget relative to the national product decreases as the level of corruption grows. Privatization is highlighted as a means of simultaneously reducing corruption and increasing efficiency. However, although privatization can have clear economic advantages, its impact on corruption is still not clear. Corruption may only thus be shifted from the

14 Retrieved from: http://www.transparency.org, access: 10.04.2018.

15 WEF (2016-2017). Global Competitiveness Report. Geneva: World Economic Forum, p. 46.

16 Bose, G. (2010). Aspects of bureaucratic corruption. School of Economics University of New South Wales, p. 5. 
public to private sector. Bribes formerly taken by public officials could be moved to employees in private companies. Many transitional economies have recorded massive corruption in the privatization programs themselves. ${ }^{17}$ This may be one of the reasons why cuts in the public sector do not reduce corruption, at least during the transition period.

Corruption can also distort the activities of the private sector, leading to an increase of the grey economy. This type of reaction at the same time disturbs the private sector and reduces the efficiency of the government. Some companies, especially from relatively uncorrupted countries, lack the skills required to conduct corrupt transactions; so, they lose market share or prefer to operate in countries with low levels of corruption. Similarly, aid providers and investors take into account the level of corruption in assessing where to invest their funds.

It is also believed that there is a close connection between corruption and poverty in the country. An increase in the Corruption Perception Index (CPI) by one index point (out of a total of ten, with a higher index indicating a lower corruption) is associated with an increase in productivity, an increase in capital inflows of $0.8 \%$ of GDP of a particular country, and an increase in per capita income of nearly 4\%. According to the World Bank estimation, corruption causes a "loss" of around billions of dollars each year. ${ }^{18}$

\subsection{Methodology and research questions}

The aim of this paper is to demonstrate the level of corruption in Serbia, as well as to examine the interdependence between the level of corruption measured by the Corruption Perception Index (CPI) and the level of national competitiveness measured by the Global Competitiveness Index (GCI).

Methods used in this paper are: analysis method, comparative analysis method, descriptive statistics, and correlation analysis. The analysis method is reflected in the elaboration of the phenomenon of corruption, in a narrow and wider sense, as well as the consideration of all its components. A special emphasis is given to the role of corruption in the macroeconomic stability of a country as one of the important determinants of national competitiveness. The comparative analysis method finds its application in a comparative analysis of the statistics from the Transparency International and World Economic Forum (WEF) database. The correlation analysis finds its application in assessing the strength of the link between corruption and national competitiveness. The statistical data analysis

17 Bjorvatn, K., Soreide, T. (2005). Corruption and Privatization. European Journal of Political Economy: Vol. 21, No. 4, pp. 903-914.

18 Retrieved from : http://www.worldbank.org/, accessed: 12.04.2018. 
was performed using the statistical program SPSS 23.0. The analysis includes Serbia and the European Union countries (28) in the period from 2009 to 2016.

To achieve the set objective, the paper is based on the following research questions:

1. Is the level of corruption in Serbia decreasing in the analysed period from 2009 to 2016 ?

2. Does Serbia have a similar level of corruption as the European Union countries?

3. Is there a relationship between corruption and national competitiveness in Serbia?

\section{Results and discussion}

The results of the research are grouped into three categories:

a) The analysis of corruption in Serbia;

b) Benchmarking analysis of Serbia and the EU countries, according to the CPI;

c) Correlation analysis of corruption and national competitiveness in Serbia.

a) The analysis of corruption in Serbia

By its nature, corruption is hidden and difficult to prove. Despite the large number of studies about its distribution, insufficient knowledge about corruption remains as a problem in a majority of countries. Corruption is a complex

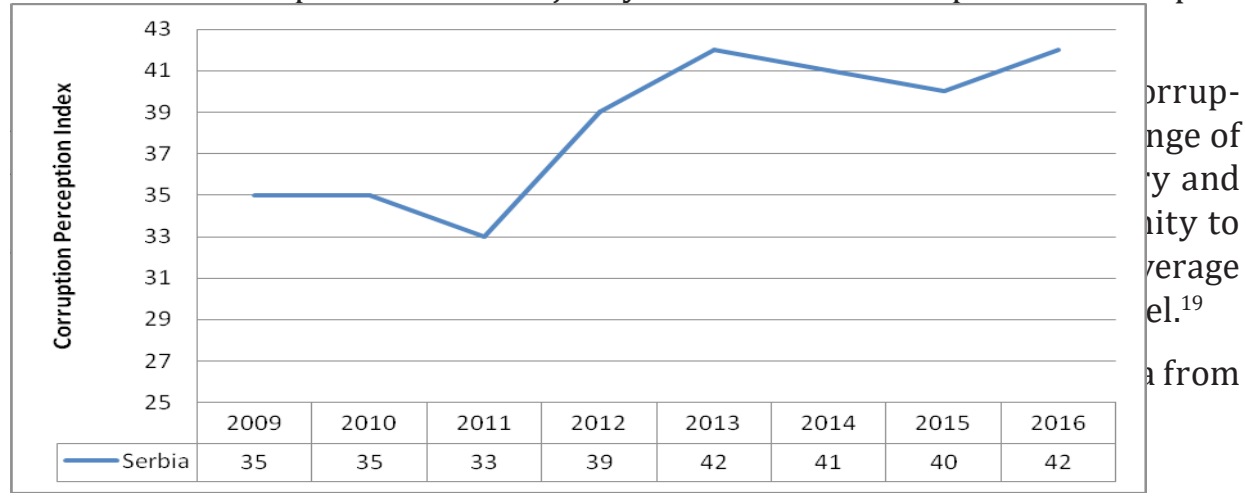

Figure 1. The level of corruption in Serbia according to the Corruption Perception Index, 2009-2016

Source: Transparency International

19 www.transparency.org 
Based on the figure above, corruption in Serbia in the period from 2009 to 2016 shows a decreasing trend (with some slight fluctuations). The lowest CPI and the highest corruption rate were recorded in 2011. On the other hand, the lowest corruption and the highest CPI of 42 were recorded in 2013 and 2016.

b) Benchmarking analysis of Serbia and the EU countries, according to the Corruption Perception Index (CPI)

Table 1 illustrates the Corruption Perception Index(CPI) in the 28 EU countries and Serbia for the period from 2009 to 2016. As a new EU member at the time, Croatia is also included in the analysis for the whole period.

Table 1. Corruption Perception Index (CPI) in the EU countries and Serbia, 2009-2016

\begin{tabular}{lcccccccc}
\hline EU 28 & $\mathbf{2 0 0 9}$ & $\mathbf{2 0 1 0}$ & $\mathbf{2 0 1 1}$ & $\mathbf{2 0 1 2}$ & $\mathbf{2 0 1 3}$ & $\mathbf{2 0 1 4}$ & $\mathbf{2 0 1 5}$ & $\mathbf{2 0 1 6}$ \\
\hline United Kingdom & 77 & 76 & 78 & 74 & 76 & 78 & 81 & 81 \\
Sweden & 92 & 92 & 93 & 88 & 89 & 87 & 89 & 88 \\
Netherlands & 89 & 88 & 89 & 84 & 83 & 83 & 84 & 83 \\
Finland & 89 & 92 & 94 & 90 & 89 & 89 & 90 & 89 \\
Denmark & 93 & 93 & 94 & 90 & 91 & 92 & 91 & 90 \\
Luxembourg & 82 & 85 & 85 & 80 & 80 & 82 & 85 & 81 \\
Ireland & 80 & 80 & 75 & 69 & 72 & 74 & 75 & 73 \\
Germany & 80 & 79 & 80 & 79 & 78 & 79 & 81 & 81 \\
Austria & 79 & 79 & 78 & 69 & 69 & 72 & 76 & 75 \\
France & 69 & 68 & 70 & 71 & 71 & 69 & 70 & 69 \\
Belgium & 71 & 71 & 75 & 75 & 75 & 76 & 77 & 77 \\
Estonia & 66 & 65 & 64 & 64 & 68 & 69 & 70 & 70 \\
Malta & 52 & 56 & 56 & 57 & 56 & 55 & 60 & 55 \\
Czech Republic & 49 & 46 & 44 & 49 & 48 & 51 & 56 & 55 \\
Spain & 61 & 61 & 62 & 65 & 59 & 60 & 58 & 58 \\
Slovenia & 66 & 64 & 59 & 61 & 57 & 58 & 60 & 61 \\
Cyprus & 66 & 63 & 63 & 66 & 63 & 63 & 61 & 55 \\
Italy & 43 & 39 & 39 & 42 & 43 & 43 & 44 & 47 \\
Portugal & 58 & 60 & 61 & 63 & 62 & 63 & 64 & 62 \\
Latvia & 45 & 43 & 42 & 49 & 53 & 55 & 56 & 57 \\
Hungary & 51 & 47 & 46 & 55 & 54 & 54 & 51 & 48 \\
Slovakia & 45 & 43 & 40 & 46 & 47 & 50 & 51 & 51 \\
Lithuania & 49 & 50 & 48 & 54 & 57 & 58 & 59 & 59 \\
Bulgaria & 38 & 36 & 33 & 41 & 41 & 43 & 41 & 41 \\
Poland & 50 & 53 & 55 & 58 & 60 & 61 & 63 & 62 \\
Greece & 38 & 35 & 34 & 36 & 40 & 43 & 46 & 44
\end{tabular}




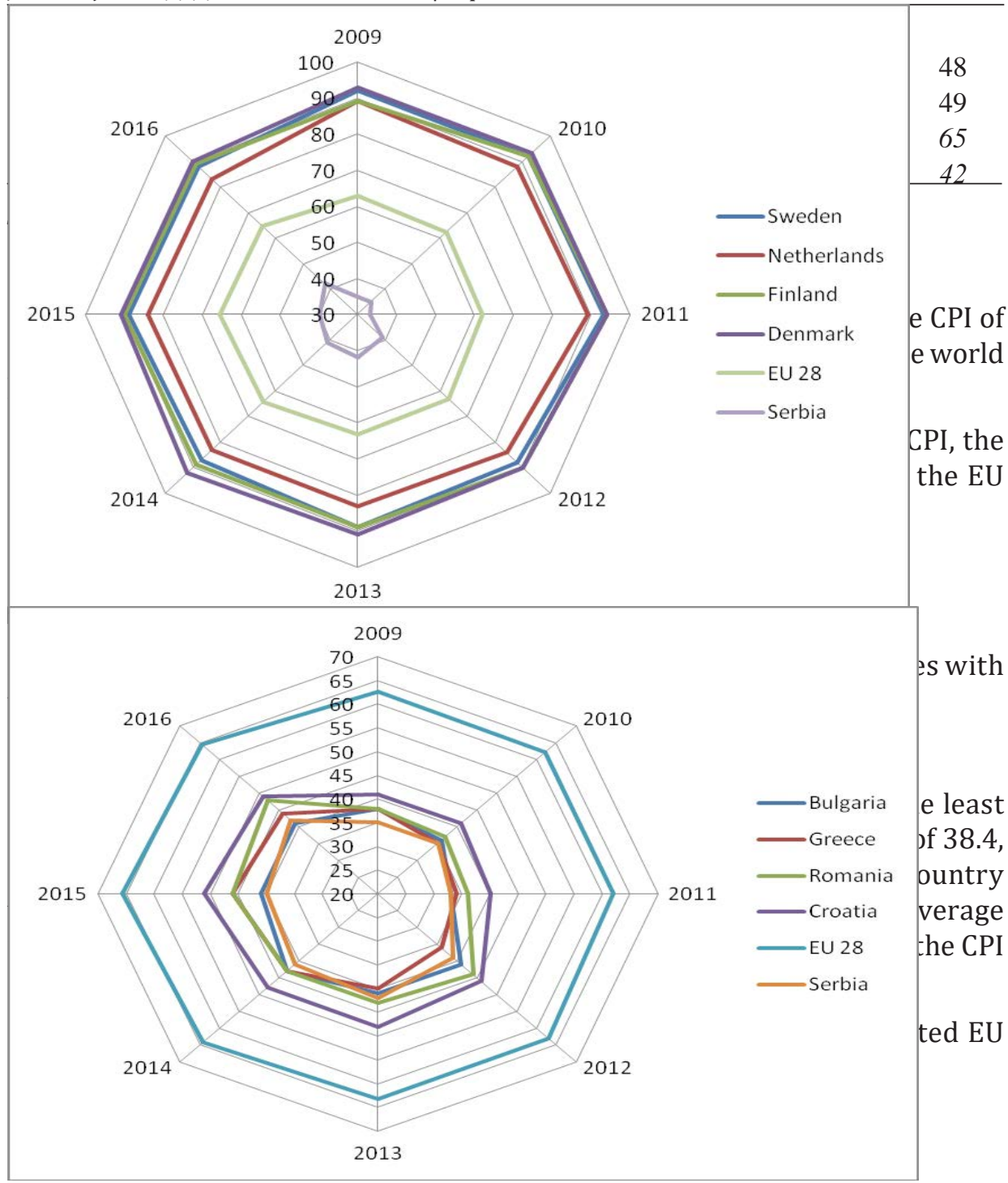

Figure 3. Benchmarking between Serbia, EU 28 average and EU countries with the lowest CPI

Based on Figure 3, it can be seen that Serbia in the whole analysed period lags behind even in comparison to the most corrupted EU countries and EU 28 average. With an average CPI value of 38.4, Serbia lags behind in comparison to Bulgaria as the EU country with the lowest CPI in the analysed period (average 39.3), Greece (average 39.5), Romania (average 41.9) and Croatia (average 45.5). 
c) Correlation analysis of corruption and national competitiveness

Table 2 illustrates the correlation analysis between the Corruption Perception Index (CPI) and Global Competitiveness Index (GCI) in Serbia from 2009 to $2016 .{ }^{20}$

The Global competitiveness index has its values range from 1 to 7 , where 1 represents the lowest and 7 the largest competitiveness. It was calculated for 133 to 148 countries worldwide. The GCI, published in the Global Competitiveness Report by the World Economic Forum, includes a weighted average of 114 indicators, each reflecting some aspect of competitiveness. These indicators are grouped in 12 different pillars. ${ }^{21}$

Table 2. Correlation coefficients between CPI and GCI in Serbia (2009-2016)

\begin{tabular}{|l|l|l|l|}
\hline \multicolumn{2}{|l|}{} & CPI & GCI \\
\hline CPI & Pearson Correlation & 1 & 0.297 \\
\hline & Sig. (2-tailed) & & 0.474 \\
\cline { 2 - 4 } & N & 8 & 8 \\
\hline GCI & Pearson Correlation & 0.297 & 1 \\
\hline & Sig. (2-tailed) & 0.474 & \\
\cline { 2 - 4 } & N & 8 & 8 \\
\hline
\end{tabular}

Source: Author's calculations (SPSS Statistics 23)

The correlation analysis revealed that there is a positive correlation between corruption and national competitiveness, indicating that the changes occur in the same direction although the degree of consistency between them is low. ${ }^{22}$ Therefore, the higher the CPI (which implies lower corruption), the higher the national competitiveness measured by the GCI.

\section{Conclusion}

Corruption is a social phenomenon of an international character. It is manifested in various forms, destroying human values and goods, hindering further social development and bringing a psychosis of insecurity, impotence, demoralization and general disorganization into the society.

Corruption is the subject of study of legal, political, international, security and social theory, as well as legal practices and criminal policies. All these activities should lead to a unified and comprehensive activity of social subjects at all le-

20 WEF (2009-2017). Global Competitiveness Report. Geneva: World Economic Forum

21 Ibid.

22 Soldić-Aleksić, J. (2011). Primenjena analiza podataka, Centar za izdavačku delatnost, Ekonomski fakultet u Beogradu, p. 180. 
vels, including the international community, aimed at to reducing, eradicating, preventing or suppressing corruption, or at least minimizing its harmful consequences at today's level of development. Due to the difficult consequences it produces, society should be organized in the fight for its prevention and suppression, both nationally and internationally. Prevention of corruption is one of the leading challenges of modern democratic change.

Even the most developed and stable societies are not immune to corrupt scandals. For this reason, it is not surprising that in contemporary societies characterized by inequality of human rights, obligations and property, the first sign of instability is the appearance of various forms of corruption. Therefore, as evidenced in the case of Serbia, a positive correlation between corruption and national competitiveness is expected. Based on the Corruption Perception Index, Serbia has decreased the level of corruption in the analysed period from 2009 to 2016. Besides, Serbia lags behind in comparison to the most and least corrupted EU countries.

Corruption is not acceptable in any modern society. It must be unavoidably eliminated at all levels and by all available means. The most important thing is to increase citizens' awareness, and to enable them to participate in the fight against corruption as the most important participant. Recognition of corruption as a problem that undermines the well-being of a society is the most important issue in the fight against corruption. It is necessary to raise citizens' awareness about its harmfulness and negative effects on the whole society in order to prevent its further spread and to take relevant action aimed at its eradication.

\section{References}

Benson, M.L., Madensen, T.D. (2007). Situational Crime Prevention and WhiteCollar Crime, in: Pontell, H.N. and G. Geis, International Handbook on White-Collar and Corporate Crime, New York: Springer.

Bjorvatn, K., Soreide, T. (2005). Corruption and Privatization, European Journal of Political Economy, Vol. 21, No. 4

Bose, G. (2010). Aspects of Bureaucratic Corruption, School of Economics, University of New South Wales

Fitzsimons, V. (2007). Economic Models of Corruption, Corruption and Development, The Anti-Corruption Campaigns.

Granovetter, M. (2004). The Social Construction of Corruption, The Norms, Beliefs and Institutions of 21st Century Capitalism: Celebrating the 100th Anniversary 
of Max Weber's The Protestant Ethic and the Spirit of Capitalism, Cornell University.

Jelačić, M. (1996). Korupcija, Ministry of Interior of the Republic of Serbia, Belgrade.

Kaufmann, D., Vicente, P.C. (2005). Legal Corruption, World Bank Institute.

Konstantinović-Vilić, S, Nikolić-Ristanović, V, Kostić, M. (2009). Kriminologija, Law Faculty, Niš.

Kreikebaum, H. (2008). Corruption as a moral issue, Social Responsibility Journal, Vol. 4 No. $1 / 2$.

MacDonald, R., Tariq Majeed, M. (2011). Causes of Corruption in European Countries: History, Law, and Political Stability, Europe's Post-Crisis Stability - An Interdisciplinary Approach, Berlin, Germany.

Milošević, Z. (2007). Političke stranke i korupcija, Political Review, no. 1, Belgrade.

Morris, S. D. (2011) Forms of Corruption, CESifo DICE Report 2/2011, Middle Tennessee State University.

Petrović, Z. (2001). Krivično delo zloupotrebe službenog položaja, Privredni kriminal i korupcija, Institute of Criminological and Sociological Research, Belgrade.

Soldić-Aleksić, J. (2011). Primenjena analiza podataka, Centar za izdavačku delatnost, Faculty of Economics in Belgrade.

Transparency International, www.transparency.org

WEF (2009-2017). Global Competitiveness Report. Geneva: World Economic Forum

World Bank, www.worldbank.org

World Economic Forum, www.weforum.org 


\author{
Др Јелена Станојевић, \\ Истраживач \\ Природно-математички факултет, Универзитет у Нишу \\ Др Дарко Димовски, \\ Ванредни професор \\ Правни факултет, Универзитет у Нишу, \\ Др Иван Милић, \\ Асистент \\ Правни факултет, Универзитет у Новом Саду
}

\title{
УТИЦАЈ КОРУПЦИЈЕ НА НАЦИОНАЛНУ КОНКУРЕНТНОСТ
}

\section{Резиме}

Корупщија је глобални феномен кога је могуће идентификовати у свим земљама. Иако свуда заступљена, корупција у већој мери погађа сиромашније земље, ограничавајући напредовање националне привреде и одузимајући средства потребна за образовање, здравство и друга јавна добра и услуге. Међутим, приватни сектор се такође суочава са овим глобалним проблемом који угрожава корпоративни идентитет, нарушава поверење између пословних партнера и који може уништити репутацију компанија. У раду се пре свега сагледавају теоријски аспекти корупције, како у јавном тако и у приватном сектору, са посебним освртом на улогу корупције у остваривању макроекономске стабилности земље. На основу Индекса перцепције корупције истражују се промене у нивоу корупције заступљене у Републици Србији у поређењу са земљама Европске уније у периоду од 2009. до 2016. године. Такође, анализира се утицај корупције на националну конкурентност како би се сагледао степен њихове међузависности. Истраживање у овом раду корисно је за креаторе јавних политика у сврху будућег усмеравања развојне политике и стратегије за борбу против корупције.

Кључне речи: корупција, конкурентност, индекс перцепције корупције. 
